\title{
Paradigma Baru Manajemen Pelayanan Publik : Memberi Nilai Tambah (Adding Value) Pelayanan Publik Bagi Masyarakat Di Daerah
}

\author{
M. Rizki Pratama \\ Program Studi Ilmu Administrasi Negara, Universitas Airlangga \\ Surabaya, Jawa Timur \\ Email : Rizkipratama90@gmail.com
}

\begin{abstract}
Abstrak
Sejak dimulainya era otonomi daerah pasca reformasi politik tahun 1998 melalui UU 22 tahun 1999 yang kemudian direvisi menjadi UU 32 tahun 2004 posisi daerah memiliki tanggung jawab yang sangat besar dalam penyelenggaraan pelayanan publik. Sejalan dengan itu daerah-daerah berusaha memperbaiki pelayanan publik dengan berbagai cara termasuk melalui inovasi pelayanan publik. Dalam konteks tersebut terdapat paradigm baru manajemen pelayanan publik yakni dengan memberi nilai tambah (adding value) pada pelayanan publik di daeerah yang dapat memberikan stimulus perubahan sosial dan ekonomi bagi masyarakat. Oleh karena itu karya tulis ini akan mengupas secara mendalam makna nilai tambah (adding value) pelayanan bagi masyarakat sebagai paradigma baru dalam manajemen pelayanan publik disertai dengan studi kasus di Kabupaten Sragen dan Kota Kediri.

Kata Kunci : Pelayanan Publik, Manajemen, Nilai Tambah (adding value)
\end{abstract}

\section{Pendahuluan}

Sejak dimulainya era otonomi daerah pasca reformasi politik tahun 1998 melalui UU 22 tahun 1999 yang kemudian direvisi menjadi UU 32 tahun 2004 posisi daerah memiliki tanggung jawab yang sangat besar dalam penyelenggaraan pelayanan publik. Sejalan dengan itu daerah-daerah berusaha memperbaiki pelayanan publik dengan berbagai cara termasuk melalui inovasi pelayanan publik. Melalui inovasi pelayanan publik tersebut diharapkan dapat meningkatkan kualitas pelayanan publik kepada masyarakat, yang semakin mudah, cepat dan murah tentunya. Hingga kini telah banyak inovasi yang dilakukan di tingkat daerah dan dalam berbagai bidang. Titik krusial dalam inovasi tersebut adalah bagaimana pelayanan publik benar-benar bisa menjangkau masyarakat dalam tingkat lokal dengan mudah, sehingga pelayanan dapat efektif dan efisien. Dikaitkan dengan reformasi birokrasi nasional yang telah bergulir mulai tahun 
2005 dan direncanakan diakhiri pada tahun 2025 harus kita akui sedikit demi sedikit mulai menunjukkan perubahan pada birokrasi nasional, meskipun masih tergolong minimalis. Dalam roadmap Reformasi birokrasi yang dilakukan oleh pemerintah berfokus pada tiga hal yaitu pertama, menghasilkan profil kelembagaan (organisasi) yang efektif, ketatalaksanaan (business process) yang ringkas, dan sumber daya manusia yang profesional. ${ }^{1}$ Sejauh ini perbaikan yang ada belum mencapai perubahan yang menjadi ekspetasi oleh masyarakat, secara substansial birokrasi sendiri juga belum mampu memberikan pelayanan publik kepada masyarakat secara berkualitas dan merata dimana pelayanan publik merupakan core business dari birokrasi.

Dengan menilik situasi masyarakat pada era saat ini yang cenderung konsumtif dengan paradigma praktis ekonomis maka kecenderungan tersebut memiliki kontribusi pada kebutuhan masyarakat pada pelayanan publik yang diberikan oleh pemerintah. Masyarakat tidak peduli apa yang dilakukan oleh pemerintah dalam segala upaya untuk memberikan perbaikan dan peningkatan pelayanan kebutuhan dasar masyarakat ${ }^{2}$, termasuk reformasi birokrasi akan tetapi yang penting adalah apa yang mereka dapatkan sekarang dari upaya pemerintah tersebut. Berdasar pada hukum ekonomi, kebutuhan manusia tidak terbatas akan tetapi alat pemenuhan kebutuhannya yang terbatas. Pemerintah yang berkewajiban menyediakan kebutuhan masyarakat, akan tetapi pemerintah juga harus tahu bahwa itu tidak pernah cukup, oleh karena itu sudah tidak relevan lagi hanya mengedepankan peningkatan kualitas pelayanan, peningkatan kompetensi sumber daya manusia, bahkan sampai dengan pemberatasan korupsi, toh masyarakat sudah mengalami kecenderungan yang apatis terhadap apa yang dilakukan oleh pemerintah dan menganggap semua itu sudah 'basi', sebagai contoh dalam pemilihan kepala daerah (pilkada) saja yang seharusnya merupakan hak warga negara untuk memilih pemimpin kini tingkat partisipasinya terus saja turun. Untuk itu seharusnya pemerintah menggunakan visi yang baru dalam memberikan pelayanan publik bagi masyarakat, yaitu pelayanan yang berbasis manfaat (benefit) bagi masyarakat. Manfaat ini terkait dengan produk inti (core business) yang diberikan oleh

\footnotetext{
${ }^{1}$ Dalam Suaedi, Falih dan Wardiyanto, Bintoro (Ed). 2010, Revitalisasi Administrasi Negara : Reformasi Birokrasi Dan E-Governance, Graha IImu, Jogjakarta. Hal 14

${ }^{2}$ Noor, Isran. 2012. Politik Otonomi Daerah Untuk Penguatan NKRI, Seven Strategic Studies. Hal 12
} 
birokrasi, akan tetapi jika berbicara manfaat yang hanya berdasar produk inti tidaklah cukup untuk saat ini sesuai dengan hukum ekonomi diatas, maka memberikan nilai tambah (adding value) pada suatu pelayanan merupakan kebutuhan yang harus dipenuhi saat ini.

Menurut Groonroos ${ }^{3}$ "For highly intangible service offerings in particular, in both a physical and mental sense, organisation-wide factors, such as the level of functional service quality, may be emphasised when value added. " berdasarkan pernyataan tersebut maka sebuah pelayanan yang sulit diukur, selain menggunakan kualitas layanan maka perlu ditekankan pada aspek nilai tambah atau value added. Nilai tambah atau value added merupakan nilai yang bertambah dari layanan yang dibutuhkan masyarakat sesuai dengan tujuan inovasi yang dilakukan dan bahkan melebihi harapan dari masyarakat itu sendiri mengenai pelayanan yang dihasilkan dari inovasi. Sedangkan nilai sendiri adalah persepsi pelanggan tentang keseimbangan antara manfaat yang diterima dengan pengorbanan yang diberikan untuk mendapatkan manfaat tersebut. ${ }^{4}$ Ketika manfaat yang dirasakan bertambah dari sebuah pelayanan maka dapat disebut dengan dengan nilai tambah atau value added. Oleh karena itu nilai tambah atau value added seharusnya menjadi penjelasan yang penting bagi sebuah pelayanan hasil inovasi karena masyarakat akan mendapatkan manfaat yang lebih baik daripada hanya hasil angka-angka berdasarkan survei statistik. Success, or superior performance, is ideally measured in terms of value added. The fundamental purpose of management is to add value. When we ask, why are some public sector organisations more successful than others? we are attempting to find why some add more value than others. ${ }^{5}$ Pernyataan diatas memberikan rekomendasi bahwa kinerja yang suskes atau superior sangat ideal untuk diukur dengan nilai tambah, yang tentu saja dalam hal ini nilai tambah bagi masyarakat. Innovation is important, not only because of its direct impact on the survival of firms, but also because of its profound effects on the paths of

\footnotetext{
${ }^{3}$ Dalam Devlin, James F. 1998, Value Added To Service Offerings : The Case Of Uk Retail Financial Services. European Journal Of Marketing. Vol. 32 (11/12). Hal 1091

${ }^{4}$ Buttle, Francis. 2007, Customer Relationship Management : Concepts And Tools, Bayumedia, Malang. Hal 282

${ }^{5}$ P.M. Jackson. 1999, Public Sector Added Value : Can Bureaucracy Deliver, Management Centre Public Centre Economics Research Centre University Of Leicester, Leicester. Hal 18
} 
social and economic change. ${ }^{6}$ Pernyataan tersebut menunjukkan bahwa inovasi harus menimbulkan pengaruh pada stimulus perubahan sosial dan ekonomi. Kemudian There is an important difference in innovation between private and public sectors. In the private sector, successful innovation is often seen to be a virtue in itself, as a means of ensuring competitiveness, whether in new markets or to revive flagging markets. This is not the case for public services, where innovation is justifiable to the extent that it increases public value in the quality, efficiency or fitness for purpose of governance or services. ${ }^{7}$ Jadi disini inovasi juga harus meningkatkan nilai publik pada kualitas, efisiensi atau kemampuan tata kelola dan pelayanan. Pengukuran keberhasilan organisasi juga harus dilakukan secara eksternal seperti pendapat dari Kaplan dan Norton ${ }^{8}$ yaitu The balanced scorecard is becoming a common management approach, not only to measure internal organisational performance but also to demonstrate and communicate externally success and value added to customers. Pengukuran secara eksternal melalui perspektif pelanggan atau pengguna layanan dalam hal ini adalah untuk mengetahui nilai tambah atau value added dari layanan bagi pengguna layanan itu sendiri.

Berdasarkan deskripsi apa itu nilai tambah ? nilai tambah terjadi ketika masyarakat mendapatkan suatu manfaat dari sebuah pelayanan diluar kewajiban utama organisasi pelayanan tersebut, sehingga memunculkan nilai-nilai yang bermanfaat yang baru dan sebelumnya tidak ada. Jika ditinjau dari terminologi sektor swasta maka manfaat nilai tambah pasti berupa loyalitas pelanggan dan keunggulan kompettitif sebuah perusahan, akan tetapi dalam konteks pelayanan publik adalah nilai tambah (adding value) dapat memberikan stimulus perubahan sosial dan ekonomi bagi masyarakat. Oleh karena itu karya tulis ini akan mengupas secara mendalam makna nilai tambah (adding value) pelayanan bagi masyarakat sebagai paradigm baru dalam manajemen pelayanan publik disertai dengan studi kasus di dua daerah.

\footnotetext{
${ }^{6}$ Hung, Shih-Chang. 2004, Explaining The Process Of Innovation : The Dynamic Reconciliation Of Action And Structure, Jurnal Sage Human Relation. Vol. 57 (11). Hal 1480

${ }^{7}$ Hartley, Jean. 2006, Innovation And Its Contribution To Improvement : A Review For Policy Maker, Policy Advisers, Managers And Researchers, Departement For Communities And Local Government, London. Hal 41

${ }^{8}$ Dalam Wilson, Chris, Leckman, Joan, Cappucino, Kahlil dan Pullen, Wim. 2001, Towards Costumer Delight : Added Value In Public Sector Corporate Real Estate, Jurnal corporate real estate. Vol 3 (3). Hal 219
} 


\section{Nilai Tambah Pelayanan (Value Added Service)}

Anandpadmanabhan ${ }^{9}$ memberikan definisi nilai tambah yang dalam hal ini adalah nilai tambah pelayanan adalah value added services refers to non-core services which are offered to the customers apart from the core or basic services being offered. Menurut Buttle ${ }^{10}$ memberikan arti nilai tambah pelayanan sama dengan memberikan manfaat tambahan kepada pelanggan yang dapat dilakukan dengan dua pendekatan, yaitu modifkasi produk dan asosiasi produk. Modifikasi produk berarti pengubahan produk sedemikian rupa sehingga lebih mengikat pada kebutuhan, nilai dan minat pelanggan. Asosiasi produk berarti menghubungkan merek dengan beberapa persoalan atau konteks yang sangat penting bagi pelanggan. Sedangkan Lovelock dan Wright ${ }^{11}$ memberikan penjelasan bahwa nilai tambah pelayanan merupakan sesuatu yang dapat menambah nilai ekstra bagi pelanggan melalui jasa pelengkap. Berdasarkan pendapat beberapa ahli diatas, nilai tambah pelayanan (value added service) merupakan manfaat yang bertambah yang dipersepsikan oleh pelanggan dari pemberian pelayanan dari sebuah organisasi pelayanan melalui jasa pelengkap atau yang disebut kembang jasa (flower of service). Berbagai macam jenis nilai tambah dalam pelayanan (value added service) menurut Eiglier dan Langeard ${ }^{12}$ dapat dijelaskan melalui penggolongan jasa pelengkap yang terbagi menjadi dua kelompok yaitu jasa pelengkap yang memudahkan (facilitating supplementary service) dan jasa pelengkap yang meningkatkan (enhacing supplementary service) yang disebut dengan kembang jasa (flower of service).

\footnotetext{
${ }^{9}$ Anandpadmanabhan, Narayanan. 2010, Value Added Service In India, Royal Institute Of Technology, Stockholm. Hal 3

${ }^{10}$ Buttle, Francis. 2007, Customer Relationship Management : Concepts And Tools, Bayumedia, Malang. Hal 297

${ }^{11}$ Lovelock, Christopher H., dan Wright Lauren K. 2007, Manajemen Pemasaran Jasa, Indeks, Jakarta. Hal 190

12 Ibid, Hal 190-203 


\section{Birokrasi Berbasis Nilai-Nilai Masyarakat Lokal}

Menurut Rokeach dan Kernaghan ${ }^{13}$ defines values as those enduring beliefs that influence the choices we make among available means or ends. Serta MacCarthaigh ${ }^{14}$ The individual principles or qualities that guide judgement and behaviour. Jadi nilai merupakan sesuatu yang sangat substansial yang ada dalam suatu birokrasi yang dapat mempengaruhi segala bentuk tindakan, perilaku serta ide-ide. Terkait dengan itu semenjak kita lahir sampai matipun harus tetap berurusan dengan birokrasi, sehingga kita tahu bahwa birokrasi memiliki impact yang luar biasa bagi kehidupan masyarakat. Nilai-nilai dalam birokrasi yang masih terbelenggu nilai weberian yang rigid, mekanis serta birokratis harus dibebaskan, jangan terbelenggu pada tugas, pokok dan fungsi (tupoksi) birokrasi yang itu-itu saja, tapi memberi nilai tambah bagi masyarakat. Basis nilai tambah harus berpatokan pada kondisi kebutuhan lokal baik berupa kearifan maupun keunikan lokal sebab hanya dengan memahami secara mendalam apa yang dibutuhkan masyarakat melalui nilai-nilai yang telah lama terakumulasi di dalam masyarakat maka akan lebih mudah untuk menginisiasi perubahan termasuk memenuhi kebutuhan masyarakat melalui campur tangan birokrasi. Misalnya ketika daerah banyak memiliki pelaku ekonomi lokal yang hanya bergantung pada usaha mikro dengan penghasilan dan modal yang terbatas maka birokrasi harus tanggap dengan menyediakan pelayanan publik yang bernilai tambah dengan cara mendatangi mereka secara langsung dan memberikan konsultasi secara mendalam sampai terjadi perubahan keadaan ekonomi mereka, karena golongan tersebut juga sangat tidak mungkin untuk datang ke office dom birokrasi untuk meminta bantuan, sebab mereka sendiri tidak memahami dan tidak berdaya.

\footnotetext{
${ }_{14}^{13}$ Dalam MacCarthaigh, Muiris. 2008, Public Service Values, Colourbooks, Dublin. Hal 8

${ }^{14}$ Ibid, Hal 9
} 


\section{Paradigma Baru Dalam Manajemen Pelayanan Publik}

Memberi nilai tambah (adding value) kepada masyarakat melalui pelayanan publik sudah seharusnya diimplementasikan oleh pemerintah. Cara-cara lama yang biasa sudah terbukti kurang mendapatkan respon secara serius oleh masyarakat. Kini birokrasi pelayanan publik harus bergerak dalam paradigma baru, tidak saja melaksanakan peraturan yang diamanatkan oleh undang-undang beserta berbagai macam peraturan turunan, tidak cukup hanya memenuhi kebutuhan dasar masyarakat akan tetapi juga memberikan nilai tambah kepada masyarakat sehingga menstimulus perubahan sosial dan ekonomi di dalam masyarakat. Ketika masyarakat sudah mendapatkan apa yang mereka inginkan, bahkan lebih dari ekspetasi mereka melalui nilai tambah yang diberikan oleh birokrasi pelayanan publik maka selanjutnya pasti akan lebih mudah mengajak masyarakat untuk bermitra dengan pemerintah menuju civil society.

\section{Studi Kasus Pemerintah Daerah : Inovasi Pelayanan Publik Dengan Memberi Nilai Tambah (Adding Value) Di Kabupaten Sragen Dan Kota Kediri}

Perspektif terbaru seperti apa yang diungkapkan diatas dapat disajikan dalam dua studi kasus di daerah berikut ini. Dimana terjadi mendesentralisasi pelayanan dari tingkat pusat ke tingkat daerah sesuai dengan konsep otonomi daerah, akan tetapi juga memiliki nilai tambah yakni pelayanan publik dapat menjangkau ke tingkat pemerintah terkecil di daerah yaitu dari kecamatan hingga desa/kelurahan dan bahkan pelayanan publik dapat menjangkau langsung masyarakat sendiri dengan mekanisme jemput bola sehingga masyarakat tidak perlu lagi datang ke lokasi birokrasi pelayanan, justru birokrasi tersebut yang akan langsung mendatangi masyarakat. Dua daerah berikut ini dapat dikatakan menjadi profil good practice dalam manajemen pelayanan publik, khususnya bagaimana men-delivery nilai tambah (adding value) pada program inovasi pelayanan publik. Berdasarkan data initiatives for governance innovation (IGI) merupakan sebuah forum kerjasama antara KINERJA-USAID dengan lima Universitas besar di Indonesia, yaitu FISIP UGM, FISIP UNAIR, FISIP UNHAS, FISIP UNSYIAH 
serta FISIP UNTAN ${ }^{15}$ menunjukkan setidaknya terdapat dua daerah dengan inovasi pelayanannya mampu memberikan nilai tambah (adding value) pelayanan bagi masyarakat di daerah, di bawah ini adalah sedikit deskripsi mengenai inovasi pelayanan publik yang dilakukan oleh dua daerah, yaitu Kabupaten Sragen dan Kota Kediri.

\section{Kabupaten Sragen : Inovasi Program Paten}

Paten merupakan akronim dari pelayanan administrasi terpadu kecamatan. Inovasi ini dilakukan oleh badan perijinan terpadu dan penanaman modal (BPTM) Kabupaten Sragen. Inovasi pelayanan ini merupakan inovasi pelayanan publik dalam bidang pelayanan perijinan yang didekatkan kepada masyarakat hingga tingkat kecamatan, artinya masyarakat dapat mengurus ijin-ijin tertentu yang semua prosedur sampai keluarnya dokumen perijinan terselenggaran di kantor kecamatan. ${ }^{16}$ Meskipun tidak melayani semua jenis pelayanan perijinan, yaitu hanya perijinan skala kecil serta tidak memerlukan kajian teknis akan tetapi inovasi ini sudah membuktikan bahwa pelayanan publik memang harus didekatkan dan dimudahkan kepada masyarakat yang membutuhkan sehingga masyarakat tidak merasa berat dalam mengurus suatu pelayanan hingga ke ibukota daerah dengan kondisi geografis yang berbeda-beda untuk menuju kesana. Memberi nilai tambah (adding value) dalam kasus adalah bagaimana birokrasi keluar dari kebiasaan (habits) yang kebanyakan kegiatan pemerintahan dan pelayanan publik bertumpu pada satuan kerja perangkat daerah (SKPD) di lbukota daerah kini justru didekatkan, dipermudah, dan ditingkatkan pelayanannya di level kecamatan sehingga masyarakat dapat menerima manfaatnya secara langsung tanpa pengorbanan yang lebih banyak lagi karena mengurus perijinan.

\footnotetext{
${ }_{10}^{15}$ www.igi.fisipol.ugm.ac.id (Diakses tanggal 1 April 2013)

16 Yuniarti. 2012, Database Good Practice Bidang Penyederhanaan Usaha : Pelayanan Adminsitrasi Terpadu Kecamatan (PATEN), Initiatives For Governance Innovation, Jogjakarta. Hal 2
} 


\section{Kota Kediri : Inovasi Program MPS}

Inovasi yang dilakukan oleh pemerintah Kota Kediri ini, lebih tepatnya dilakukan oleh kantor pelayanan perijinan Kota Kediri yang membuat terobosan pelayanan perijinan yang mendatangi masyarakat secara langsung dengan menggunakan mobil sehingga disebut mobile public service (MPS). ${ }^{17}$ Pelayanan perijinan ini memfokuskan pada pelayanan surat ijin usaha perdagangan (SIUP) dan tanda daftar perusahaan (TDP) bagi usaha mikro, kecil dan menengah (UMKM) agar memiliki legalitas usaha sehingga dapat mengajukan pinjaman modal ke berbagai bank. Masyarakat tinggal nomor telepon kantor pelayanan perijinan dan mobil MPS dapat segera meluncur ke lokasi yang diharapkan oleh masyarakat. Inovasi ini merupakan model pelayanan jemput bola yang memudahkan masyarakat dalam mendapatkan pelayanan publik. Hal yang sama dengan Kabupaten Sragen dalam hal ini adalah Kantor Pelayanan Perijinan (KPP) Kota Kediri memberi nilai tambah (adding value) pelayanan dengan cara-cara baru yakni dengan layanan jemput bola yang jelas-jelas berbeda (difference) dan unik (distinctive) guna mempermudah dan meningkatkan pelayanan perijinan bagi masyarakat di Kota Kediri.

\footnotetext{
${ }^{17}$ Rizki Pratama, M., dan Styawan, Suci. 2012, Database Good Practice Bidang Penyederhanaan Usaha : Program Mobile Public Service Kantor Pelayanan Perijinan Kota Kediri, Initiatives For Governance Innovation, Jogjakarta. Hal 2
} 


\section{Penutup}

Memberi nilai tambah (adding value) pelayanan publik dengan jalan mendekatkan, mempermudah, serta meningkatkan pelayanan dengan cara-cara yang diluar kebiasaan (habits) baik melalui inovasi maupun deskresi seperti menggeser pusat pelayanan hingga ke tingkat lokal yakni hingga tingkat kecamatan dan bahkan dengan sistem jemput bola merupakan kabar baik bagi perkembangan reformasi birokrasi yang sedang dilaksanakan pemerintah saat ini dan tentu saja daerah serta masyarakat mendapatkan manfaat yang sangat luar biasa dari otonomi daerah. Dalam konteks ini merupakan paradigm baru dalam manajemen pelayanan publik yaitu dengan adanya cara-cara baru dengan memberi nilai tambah (adding value) pelayanan bagi amsyarakat di daerah. Dari dua contoh diatas adalah pelayanan dalam bidang perijinan, akan lebih hebat lagi jika ada usaha-usaha yang dilakukan dalam pelayanan di bidang lainnya, terutama dalam pelayanan yang sifatnya administratif yang terkenal berbelitbelit. Akan sangat tidak efisien sekali jika masyarakat di tingkat desa harus mengurus administrasi ke pusat pemerintahan dengan jarak berpuluh-puluh kilometer dan bahkan hingga puluhan kilometer hanya untuk mendapatkan sebuah dokumen. Paradigma baru ini harus segera menjadi trend bagi seluruh daerah karena dampaknya akan sangat besar bagi masyarakat itu sendiri, misalnya dari pelayanan perijinan yang dicontohkan di atas dapat memberikan stimulus perekonomian di tingkat lokal sehingga menciptakan kesejahteraan bersama. Kemudian dari usaha-usaha member nilai tambah (adding value) yang dilakukan oleh pemerintah daerah ada baiknya untuk segera dipetakan, dievaluasi secara komprenhensif sehingga dapat dijadikan pembelajaran bersama ke depannya, good practice dapat menjadi sustainable serta membuka peluang replikasi bagi daerah-daerah lain yang ingin mendapatkan manfaatnya. 


\section{Daftar Pustaka}

Anandpadmanabhan, Narayanan. 2010, Value Added Service In India, Royal Institute Of Technology, Stockholm.

Buttle, Francis. 2007, Customer Relationship Management : Concepts And Tools, Bayumedia, Malang.

Dalam Devlin, James F. 1998, Value Added To Service Offerings : The Case Of Uk Retail Financial Services. European Journal Of Marketing. Vol. 32 (11/12).

Hartley, Jean. 2006, Innovation And Its Contribution To Improvement : A Review For Policy Maker, Policy Advisers, Managers And Researchers, Departement For Communities And Local Government, London.

Hung, Shih-Chang. 2004, Explaining The Process Of Innovation : The Dynamic Reconciliation Of Action And Structure, Jurnal Sage Human Relation. Vol. 57 (11).

Lovelock, Christopher H., dan Wright Lauren K. 2007, Manajemen Pemasaran Jasa, Indeks, Jakarta.

MacCarthaigh, Muiris. 2008, Public Service Values, Colourbooks, Dublin.

Noor, Isran. 2012. Politik Otonomi Daerah Untuk Penguatan NKRI, Seven Strategic Studies.

P.M. Jackson. 1999, Public Sector Added Value : Can Bureaucracy Deliver, Management Centre Public Centre Economics Research Centre University Of Leicester, Leicester.

Rizki Pratama, M., dan Styawan, Suci. 2012, Database Good Practice Bidang Penyederhanaan Usaha : Program Mobile Public Service Kantor Pelayanan Perijinan Kota Kediri, Initiatives For Governance Innovation, Jogjakarta.

Suaedi, Falih dan Wardiyanto, Bintoro (Ed). 2010, Revitalisasi Administrasi Negara : Reformasi Birokrasi Dan E-Governance, Graha llmu, Jogjakarta.

Wilson, Chris, Leckman, Joan, Cappucino, Kahlil dan Pullen, Wim. 2001, Towards Costumer Delight : Added Value In Public Sector Corporate Real Estate, Jurnal corporate real estate. Vol 3 (3).

www.igi.fisipol.ugm.ac.id (Diakses tanggal 1 April 2013)

Yuniarti. 2012, Database Good Practice Bidang Penyederhanaan Usaha : Pelayanan Adminsitrasi Terpadu Kecamatan (PATEN), Initiatives For Governance Innovation, Jogjakarta. 